\title{
Capital destrutivo e as chamadas "violências inocentes": uma análise da tragédia de Brumadinho sob a ótica da responsabilização civil
}

\author{
Destrutive capital and the calls "innocent violences": an analysis of \\ Brumadinho tragedy under the view of civil responsibility \\ DÉBora De Jesus REZENDE BARCELOS \\ Pontifícia Universidade Católica de Minas Gerais
}

Carolina de Souza Novaes Gomes Teixeira

Pontifícia Universidade Católica de Minas Gerais.

RESUMo Recentemente vivenciamos o horror do maior acidente de trabalho da história do Brasil. O rompimento da barragem I da Mina do Córrego Feijão em Brumadinho matou, em questão de segundos, centenas de trabalhadores e demais moradores da região, levando com eles inúmeros sonhos, além da esperança de um bom futuro. Desde então, um profundo sentimento de tristeza e irresignação tem tomado parte de toda a população. Afinal, por que isso não foi evitado? Por que a sirene não tocou? Por que os trabalhadores não foram avisados? Diante de tantos questionamentos sem respostas, o presente ensaio tem enquanto objetivo trazer à tona o caráter ambicioso, destrutivo e selvagem ínsito à atividade econômica capitalista em sua ânsia pelo lucro. Como hipótese, abordar-se-á a importância de uma responsabilização cível e trabalhista justa, fundada em verdadeiros princípios de equidade e de dignidade da pessoa humana, que deverão ser contemplados pelos magistrados em seu ofício, inclusive para deter os absurdos inconstitucionais que o poder legislativo "negociador" insiste em legitimar com a reforma trabalhista. A metodologia utilizada passará pelo método monográfico analítico, fazendo uso do levantamento bibliográfico e do estudo de material doutrinário enquanto técnica de investigação.

Palavras-chave: Capitalismo. Acidente de Trabalho. Responsabilidade Civil.

AbSTRACT We recently experienced the horror of the greatest work accident in Brazilian history. The rupture of dam I of the Mine of Córrego Feijão in Brumadinho killed, in a matter of seconds, hundreds of workers and other residents of the region, taking with them innumerable dreams, besides the hope of a good future. Since then, a deep sense of sadness and irresignment has been part of the whole population, after all, why was not this avoided? Why did not the siren ring? Why were the workers not warned? In the face of so many 
unanswered questions, this essay aims to bring to the surface the ambitious, destructive and savage nature of capitalist economic activity in its eagerness for profit. As a hypothesis, the importance of a fair civil and labor liability, founded on true principles of equity and dignity of the human person, will be considered, which should be contemplated by the magistrates in their office, including to stop the unconstitutional absurdities that power legislative "negotiator" insists on legitimizing with the labor reform. The methodology used will go through the analytical monographic method, making use of a bibliographical survey and the study of doctrinal material as a research technique.

Keywords: Capitalism. Work accident. Civil Responsability.

\section{INTRODUÇÃo}

O rompimento da barragem I da Mina do Córrego Feijão em Brumadinho, para além do sofrimento e das implicações de urgência e emergência destinadas a minimizar os efeitos catastróficos da tragédia, impõe a necessidade de refletir, analisar e discutir tantos outros fatos, a fim de que efetivamente se promova uma devida e justa reparação pelo evento, bem como, se impeça que novas tragédias como essa ocorram.

No caso específico do rompimento de barragens, uma questão alarmante é a extensão geográfica, a amplitude da população afetada, o tamanho da destruição ambiental e a longevidade dos impactos sociais, que indubitavelmente haverão de atravessar gerações.

Diante de tão grande estrago, não podemos nos deter, porém, apenas à limitada circunscrição do campo indenizatório, embora se trate de uma medida de suma importância e que será objeto do presente estudo. É preciso ir mais além, de modo a alcançar a raiz do problema, qual seja, o modelo de desenvolvimento predatório que o capitalismo selvagem nos envolve.

Nesse sentido, buscar-se-á trazer à reflexão o caráter destrutivo do capital em sua corrida pelo lucro e as sequelas de tal ambição, cujo ônus é sempre arcado pela parte mais fraca: os trabalhadores. Para, somente após, uma vez desmistificada a máscara que esconde a exploração e o desinteresse pela pessoa humana sob o emblema de modelo econômico vetor do progresso econômico e social, proceder à discussão acerca da responsabilidade civil e trabalhista da empresa em tais circunstâncias.

Por fim, passaremos por uma exposição a respeito dos problemas práticos que as vítimas não só da tragédia de Brumadinho, como também de outros tantos acidentes de trabalho haverão de enfrentar em virtude do novel artigo 223-G, introduzido na CLT pela "reforma", trazendo à baila a premente necessidade da declaração de sua inconstitucionalidade, tendo em vista o imperativo de uma leitura pós-positivista da legislação, que contemple os princípios e valores constitucionais, especialmente a dignidade da pessoa humana enquanto medida máxima de dizer o direito, sobretudo em tempos de guerra, quando as leis já não correspondem à justiça.

\section{O CARÁtER DESTRUTIVO DO CAPITAL}

O capitalismo, desde sua origem, teve enquanto objetivo fundamental a maximização do lucro, a constante acumulação de capital e o bem-estar de uma classe em detrimento da 
de outra. Sua finalidade, portanto, jamais fora a efetiva libertação geral dos povos da opressão e da tirania, apesar de ter adotado tal discurso durante a Revolução Francesa para obter o apoio e a força das massas de pobres e camponeses já famintos e que correspondiam, na época, a cerca de $80 \%$ da população. Com efeito, a Revolução e a derrocada do Antigo Regime ancorado no feudalismo e nos infindáveis privilégios da monarquia absoluta, da nobreza e do clero não seria possível pela simples indignação e revolta de uma minoria militante e instruída "nascida" do comércio. Entretanto, por sua vez, a mobilização de grandes massas seria capaz de fornecer a centelha necessária para explodir o barril de pólvora na França e, assim, alcançar a Revolução almejada (HOBSBAWM, 1977).

A luta era por uma exploração eficiente da terra, por um comércio e uma empresa livres da intervenção do Estado, por uma administração eficiente e padronizada, com tributação racional e imparcial e pela abolição de todas as restrições e desigualdades sociais entre a nobreza e a burguesia que impediam o desenvolvimento da economia e dos recursos nacionais.

Mais especificamente, pode-se dizer que as exigências do burguês foram delineadas na famosa Declaração dos Direitos do Homem e do Cidadão de 1789. Esse documento, no entanto, tratava-se de um mero manifesto contra a sociedade hierárquica de privilégios nobres e não de uma declaração em favor de uma sociedade democrática e igualitária.

"Os homens nascem livres e iguais perante as leis", dizia seu primeiro artigo, mas ela também previa a existência de distinções sociais, ainda que "somente no terreno da utilidade comum", consagrando, assim, tão-somente uma igualdade formal, já que a igualdade material era mais que contrária aos interesses dos "iluminados". A propriedade privada, por conseguinte, foi contemplada enquanto um direito natural, sagrado, inalienável e inviolável, ao passo em que as profissões se tornaram abertas ao talento, "mas, se a corrida começasse sem handicaps, era igualmente entendido como fato consumado que os corredores não terminariam juntos" (HOBSBAWM, 1977, p. 91).

Ademais, a declaração também afirmava que todos os cidadãos tinham o direito de colaborar na elaboração das leis desde que por intermédio de seus "representantes". Mas a assembleia representativa que fora constituída para tanto era composta unicamente por uma oligarquia de burgueses e possuidores de terra, não havendo pessoas democraticamente eleitas. O que não é de se espantar, já que a democracia nunca foi um regime efetivamente almejado pelos burgueses.

Assim, uma vez consagrada a Revolução Francesa, a queda dos feudos mudou apenas as formas de dominação, mas a opressão contra as partes mais fracas persistiu. Com a burguesia no poder, a exploração feudal se metamorfoseou em exploração capitalista, com a expropriação dos camponeses de todos os seus mecanismos e meios de produção a fim de que não tivessem outro caminho, senão a subordinação e servidão ao novo sistema. Desvinculados da terra que lhes garantia o sustento, o campesinato teve então de vender sua força de trabalho em troca de salário para manter-se. Era o nascimento do trabalhador assalariado, notadamente subjugado pela ordem capitalista, posto que dependia daquele emprego para viver (MARX, 2011).

Nas palavras de Marx (2011, p. 962):

[...] o movimento histórico que transforma os produtores em trabalhadores assalariados aparece, por um lado, como a libertação desses trabalhadores da 
servidão e da coação corporativa. [...]. Por outro lado, no entanto, esses recém-libertados só se convertem em vendedores de si mesmos depois de lhe terem sido roubados todos os seus meios de produção, assim como todas as garantias de existência que as velhas instituições feudais lhes ofereciam.

Dessa feita, diante do imperativo desejo de legitimar e potencializar os "fabulosos" resultados já alcançados com a nova ordem, a regência do capital passaria a desenvolver um movimento de expansão e produção de riquezas ainda maior, que só poderia se desencadear com a exploração dos novos trabalhadores. Assim, valendo-se da necessidade existencial dos novéis obreiros, o capital elevou a exploração de tal forma, que estes passaram a assumir tarefas cada vez mais pesadas, com salários aviltantes e jornadas extremamente dilatadas, cujos riscos à saúde e à integridade física eram corriqueiros, já que o capital jamais se importara com o bem-estar de seus subordinados, que deveriam inclusive, se necessário fosse, serem sacrificados em prol da boa e perfeita rentabilidade.

É que, conforme mencionado alhures, a luta da burguesia ascendente contra os privilégios e as iniquidades tiranas nunca fora na verdade em favor dos oprimidos, mas tão-somente em favor de benesses próprias, benesses essas cujo alcance e manutenção dependeriam de uma série de atrocidades que em pouco se diferenciavam dos antigos modos, senão, para pior, mas que ainda assim assumiriam o risco de cometer, passando-se seja lá sobre o que quer que fosse para alcançar os objetivos almejados, inclusive, sobre as pessoas.

Nisso reside o caráter destrutivo do capital, a corrida pelo lucro e pela contínua reprodução do movimento necessário à acumulação o leva a acionar seus mais extremos instrumentos de espoliação, de roubo, de logro, e, principalmente, da extração do último fôlego de trabalho, empregando sempre métodos muito violentos, que mesmo na atualidade ainda não caíram em desuso, ao contrário, foram potencializados por outros, muitos deles oficializados pelo Estado e que se revelam tão truculentos quanto os anteriores (PINASSI, 2009).

São as chamadas "violências inocentes", apresentadas como a consequência de uma racionalidade econômica totalmente irracional, que quanto mais demanda a implicação pessoal dos assalariados em prol do sucesso da empresa, tanto maior insignificância lhes delega, deixando-os totalmente abandonados aos riscos da atividade, já que é demasiadamente caro reduzir os riscos à saúde e segurança do trabalho, sobretudo, quando a vida e a dignidade do trabalhador já não interessam face à "supremacia" da empresa (GAULEJAC, 2007).

Por conseguinte, em nome da "modernização" e da "inovação", o capital acaba por arriscar-se ao "holocausto" de suas próprias tropas por meio da tomada de uma série de decisões direcionadas a uma redução de custos totalmente descabida, sobre a qual não fora feita qualquer discussão prévia a respeito das consequências sociais, ambientais e humanas que tal ação ou omissão poderia incorrer.

Tais violências somente são possíveis porque têm como fonte um sistema opaco. A destruição é fruto de uma escolha estratégica, efeito de um sistema de poder abstrato, distante do concreto, ocupado por pessoas que não sofrem suas consequências.

Segundo Vincent de Gaulejac (2007, p. 214), as violências inocentes: 
tes. Elas são geradas por pessoas "de bem", pessoas "morais", apoiadas pela legitimidade que é conferida pela notabilidade, pelos diplomas e pela segurança de ter razão. Violências "inocentes", porque o próprio direito acaba justificando-as e porque o próprio Estado fornece seu concurso para pô-las em prática.

Os resultados não poderiam ser outros, para além da barbárie inegavelmente empreendida em tempos antigos, hoje, os números ainda são alarmantes. Segundo a Organização Internacional do Trabalho (OIT), a cada 15 segundos um trabalhador morre em decorrência de acidentes ou doenças relacionadas ao trabalho, perfazendo um total equivalente a 321 mil mortes por ano por acidentes de trabalho e 2,02 milhões de mortes anuais em razão de doenças do trabalho. Somente no Brasil, que ocupa o quarto lugar no ranking mundial, são 700 mil acidentes de trabalho por ano, sendo que, no mínimo, três mil são fatais (OIT..., 2013).

Tudo isso é reflexo de uma dissociação entre o capitalismo e a moral, assim compreendida à luz kantiana enquanto o respeito à pessoa humana como fim em si mesmo, iniciada desde os primórdios do capitalismo, já que a rentabilidade financeira se tornou a principal finalidade do "negócio" (GAULEJAC, 2007).

Assim, vê-se cada vez mais discursos que cobrem com intenções louváveis práticas que são menos notáveis. A importância da proteção ao meio ambiente, a consideração do pessoal, a boa governabilidade e a função social da empresa, exaustivamente defendidos pelo capital nos mapas das grandes multinacionais e em seus discursos televisivos, escondem os assassinatos, os desastres ambientais, os excessos, os maus-tratos, a opressão, a violência, o corte de direitos, a mentira e a deslealdade, considerados imprescindíveis na conquista da vitória.

Não é sem razão que Mandel, citado por Pinassi (2009, p. 87), concebe o romance policial enquanto o gênero mais apropriado a narrar a história da sociedade burguesa. Em suas palavras "[...] a sociedade burguesa, por si mesma, gera o crime, tem origem no crime e conduz a ele; ou talvez porque a sociedade burguesa seja, em resumo, uma sociedade criminosa".

Com efeito, à medida que avançam as décadas e os fatos brutais, o lado do capital mantido à distância das páginas policiais começa finalmente a frequentá-la, explicitando suas próprias e profundas ramificações com o submundo que efusivamente prometeu combater, mas, ao contrário, com o qual tornou-se seu cúmplice mais promissor.

As empresas, porém, ainda assim parecem cortar-se em relação a todo o restante da sociedade, como se seus princípios de legitimação interna as liberassem de assumir as consequências sociais e humanas de suas escolhas, o que deflagra a mais verdadeira condição daquilo que se chama de impunidade, produto de um sistema alicerçado em trapaças, fraudes, vigarices, calotes, ardis, tramoias, trambiques, enfim, na corrupção.

Afinal, as cadeias jamais foram feitas para abrigar os ricos, executivos, capitalistas e grandes diretores de empresas, mas sim os pobres, famintos, insurrectos, de qualquer modo condenados, posto que não se enquadram na desejada condição de consumidores. A diferença pois, entre os bandidos que vão para a cadeia e os bandidos que não vão para a cadeia, é que para aqueles que não vão para a cadeia o crime é oportunidade de acumular capital e ascender ainda mais à posição de burguês, a fim de conquistar todos os benefícios que tal status quo oferece, independentemente de qualquer moral ou princípios éticos, ao passo que, para os bandidos que verdadeiramente vão para a cadeia, o trabalho desenvolvido no interior 
da atividade criminosa, se é que esta efetivamente veio a ocorrer, se deu enquanto um meio de vida, muitas vezes, a única alternativa restante à sua subsistência (PINASSI, 2009).

Diante disso, resta evidente que o sistema socioeconômico de capital somente se alarga, se legitima e se enaltece graças à universalização da degradação e sob um ônus pelo qual a classe trabalhadora, sem qualquer possibilidade de escusa, tem continuamente de arcar.

Sobretudo, mais recentemente, quando a História tem conseguido reproduzir, com grau ainda maior, o completo encarniçamento da classe obreira. É o caso do rompimento da Barragem I da Mina do Córrego Feijão na cidade de Brumadinho, Minas Gerais, no último dia 25 de janeiro de 2019. Uma corrente de lama e detritos inundou, matou, feriu, sufocou, de modo brutal, centenas de trabalhadores impedidos de gritar por socorro, soterrados por toneladas e toneladas de uma substância mortífera, produto do descaso, da irresponsabilidade e da ganância.

No caso específico da mineração, segundo informações obtidas diretamente no site da Organização Internacional do Trabalho (OIT), a respectiva atividade corresponde ao ramo mais perigoso do mundo no quesito acidentes e doenças do trabalho (MINING..., 2019). O que não é surpresa alguma, considerando as peculiaridades da atividade que se desenvolve corriqueiramente no subterrâneo, além da movimentação de grande porte e do uso de produtos tóxicos. Todavia, é patente que para atividades que envolvem um risco maior de dano, deve haver um cuidado ainda maior com políticas e práticas de segurança e proteção ao trabalho, o que não ocorre, pois o humano transformou-se em mero recurso da empresa.

Ademais, nos últimos anos, os malefícios das indústrias mineradoras têm se tornado cada vez mais perniciosos. Com o capital volátil e a queda do valor das commodities minerais, para não publicar resultados que acarretariam na insatisfação de acionistas, as empresas tentam cortar gastos ao máximo, o que significa que a manutenção de barragens e a conservação ambiental são postas de lado em prol de garantir as supostas exigências do mercado financeiro, entre elas, as elevadas taxas de rentabilidade a serem embolsadas pelas elites de acionistas que, em sua maioria, são estrangeiros, enquanto para os trabalhadores e a população local restam apenas as consequências de atitudes negligentes, os rejeitos e a destruição provocada (ANDREONI, 2019).

No entanto, apesar dessa intensificação, o processo de destruição da vida humana e do meio ambiente tem base secular. Somente em Minas Gerais, que carrega a mineração no nome, as mortes provocadas existem desde o ciclo do ouro e atravessam gerações. $\mathrm{O}$ primeiro registro oficial de trabalhadores mortos em uma mina conta com mais de um centenário. No dia 10 de novembro de 1886, a estrutura da Mina Velha do Complexo Morro Velho, da AngloGold Ashanti desabou em Nova Lima. Até hoje circulam versões na cidade de que morreram mais de cem obreiros no acidente, no entanto, como a mina já houvera sido alvo de um incêndio em 1867 e de uma inundação em 1871, pode ser que as histórias se misturem, já que o único registro oficial do acidente contido no livro "A Charmers Miscellany", escrito por Ian Chalmers, neto do fundador, conta com dez mortes (ARIADNE; PIZARRO; LAGÔA, 2019).

Mas foi em 1986 que o Estado enfrentou o primeiro rompimento de barragem, que se deu na Mina Fernandinho em Itabirito, Região Central, matando sete pessoas (ARIADNE; PIZARRO; LAGÔA, 2019). 
Já em 2014, no dia 26 de agosto, um operário da Vale morreu no desabamento de um túnel na Mina do Pico, também em Itabirito. Menos de um mês depois, a cidade sofreu novamente as agruras de sediar a atividade mineradora com o rompimento da barragem de rejeitos da Herculano Mineração, matando pelo menos três pessoas (ARIADNE; PIZARRO; LAGÔA, 2019).

Porém, a barbárie não parou por aí, em 5 de novembro de 2015, apenas três anos antes da tragédia de Brumadinho, experimentamos o maior desastre ambiental do país com o rompimento da barragem de Fundão, de propriedade das empresas Samarco, Vale e BHP Billinton em Mariana. Mais de 43,7 milhões de $\mathrm{m}^{3}$ de rejeitos atingiram os afluentes do rio Doce, atravessando mais de 500 quilômetros em dois Estados, até chegar ao Oceano Atlântico, deixando milhares de moradores sem água e sem trabalho. Para além, mais de 11 toneladas de peixes mortos foram retiradas dos rios, nove mil pessoas perderam suas casas e 19 pessoas morreram (sendo 14 trabalhadores, destes, 13 terceirizados) (SENRA, 2019).

Verificadas à época as causas do rompimento, a Superintendência Regional do Trabalho e Emprego de Minas Gerais (SRTE-MG) constatou inúmeras falhas na segurança da barragem como a ausência ou inexistência de dispositivos de monitoramento, falta de manutenção preventiva, não eliminação de risco conhecido, falta de critérios para correção de inconformidades e ausência de projeto (GALVÃO, 2019).

Conforme se denota, tudo isso é resultado da superexploração dos trabalhadores e da indiferença socioambiental ínsita da atividade mineradora em sua sanha pelo lucro. E o mais incrível é que até hoje os trabalhadores e moradores do município de Bento Rodrigues, em Mariana, ainda não foram indenizados, quanto menos, viram suas casas reconstruídas, construções essas que sequer tiveram início.

Mas o que esperar de um Estado que se encontra a serviço do capital?

Apenas dois meses depois da tragédia de Mariana, em janeiro de 2016, enquanto as autoridades ainda tentavam controlar o alcance da lama, o governo estadual de Minas aprovou a lei 21.972/16, que acelerava processos de licenciamento ambiental.

Já em dezembro de 2017, o Conselho Estadual de Política Ambiental (Copam) aprovou a Deliberação Normativa 217, que encurtou o processo de licenciamento ambiental de três etapas para uma, a partir de um dispositivo que ficou conhecido como fast-track, ${ }^{1}$ que inclusive, rebaixou o risco da Barragem I da Mina do Córrego Feijão que se rompera.

Enquanto isso, projetos que efetivamente endurecem regras para barragens são vetados na Assembleia de Minas. Em dezembro de 2018, o Conselho Estadual de Política Ambiental e a Secretaria de Meio Ambiente e Desenvolvimento Sustentável aprovaram licença requerida pela Vale para ampliar a capacidade da Mina da Jangada e da Mina Córrego do Feijão de 10,6 milhões de toneladas de ferro para 17 milhões de toneladas por ano. Aliás, convém dizer que desde o desastre de Mariana até o de Brumadinho, a Companhia obteve todas as licenças requeridas em Minas Gerais (FONSECA, 2019).

Para piorar o quadro, o Brasil não avançou em fiscalização de barragens, ao contrário, existe uma ausência gigantesca de fiscalização e monitoramento de obras de grande porte e

1 Fast-track, ou, "faixa-rápida" é a forma como ficou conhecido o último processo de licenciamento ambiental aprovado em dezembro de 2017, em Minas Gerais, que reduziu as etapas de licenciamento, inclusive de barragens, de três para uma, acelerando o processo. 
risco que demandam muito além de um simples processo de licenciamento, mas uma intervenção efetiva com o acompanhamento de perto por meio de medidas e ações de prevenção (FERREIRA; PORTO, 2019).

Contudo, como seria possível? Uma vez que a Agência Nacional de Mineração detém apenas 160 funcionários para fiscalizar as 790 barragens de mineração no país? (ANDREONI, 2019).

A realidade é que o Estado, amparado pelo discurso neoliberal de que a "mão invisível" é plenamente suficiente para regular e gerir todas as repercussões sociais e ambientais oriundas da atividade econômica, acaba delegando essas e outras atribuições às próprias mineradoras, que por sua vez tendem a escolher auditores que ofereçam a opinião mais fácil, rápida e barata possível, colocando em risco a vida de milhares de pessoas, o que demonstra que a famosa teoria do laissez-faire laissez-passer ${ }^{2}$ é totalmente ineficaz e desastrosa.

Não obstante tamanha inércia estatal, a Agência Nacional de Mineração é ainda considerada pelo Tribunal de Contas da União o segundo órgão mais exposto a fraudes, nepotismo e corrupção (PASSARINHO, 2019).

Tudo isso é produto da "expressão da vontade dos conquistadores enunciando como eles querem governar seus súditos” (WINSTANLEY apud PINASSI, 2009).

Com efeito, a bancada do capital é forte no Congresso. Cada vez mais homens políticos tornam-se homens de negócios e cada vez mais homens de negócios tornam-se homens políticos sem qualquer experiência. Ademais, opressores ricos e ávidos financiam as campanhas daqueles que apoiam a sua opressão, criando a "turma da lama" do Poder Legislativo, bastante atuante em barrar normas protetivas e flexibilizar as até então existentes, o que faz das leis mais um instrumento de dominação e controle do capital sobre o trabalho (FERREIRA; PORTO, 2019).

Observa-se, pois, que o problema não reside apenas na empresa, mas também no monitoramento, no licenciamento, na legislação, na punição, enfim, no Estado. O que nos leva a crer que as chances de ocorrência de novas tragédias causadas pela inconsequência do sistema são grandes.

Diante de tamanha dissolução, temoroso em perder sua afirmação social, o capital assevera que nunca mais! Aqueles, porém, que já conhecem das falácias mistificadoras, no entanto, interpelam: Nunca mais, até quando?

\section{A CIDADE De BRUMADINHO: SEQUELAS DE UMA EXPLORAÇÃo DESMEDIDA}

Era hora do almoço naquela sexta-feira ensolarada do dia 25 de janeiro.

Às 12h28, um barulho parecido com o de um incêndio começou. A parede de sustentação da Barragem I da Mina do Córrego do Feijão, de 86 metros de altura, havia desmoronado.

Em segundos, um mar de lama sobreveio, destruindo o centro administrativo e o refeitório da empresa Vale S.A. além de parte da comunidade local, ceifando vidas, sonhos

2 Expressão francesa muito utilizada no período do liberalismo econômico para designar que o mercado deve funcionar livremente, sem a interferência do Estado e que, basicamente, significa "deixai fazer, deixai ir, deixai passar" (Trad. do autor). 
e a esperança de um bom futuro não apenas dos mais de trezentos mortos, mas também de todos os moradores da cidade.

Com ares de interior, Brumadinho é um município em que todos se conhecem, não há sequer um único habitante que não tenha perdido um parente, um grande amigo ou, ao menos, um vizinho, o que gerou uma profunda tristeza na população local que, sem dúvidas, ficará marcada para sempre.

Os moradores experimentaram acordados um pesadelo infinito. Sem dormir, buscaram aplacar a angústia nas ruas, sentados nas calçadas na porta de suas casas, olhando para a serra desolada, enquanto se aproximavam outros vizinhos e amigos, igualmente sofridos, para uma prosa que apenas refletia dor e uma incansável busca por respostas.

A cidade de Brumadinho é uma cidade tranquila, sendo rara qualquer ocorrência de criminalidade, ao contrário, os moradores sempre viveram em plena harmonia uns com os outros, em um verdadeiro espírito de fraternidade, espírito esse que potencializou os efeitos destrutivos da tragédia.

Com efeito, embora já se tenha uma dimensão do impacto ambiental e humano do desastre, que inclusive foi reconhecido como o maior desastre com barragens de mineração do mundo no quesito vidas e o maior acidente de trabalho da história do país, superando o desabamento das obras do Pavilhão da Gameleira, em 1971, os efeitos da tragédia se mostram muito mais amplos do que se poderia esperar.

Especialistas da Fiocruz apontam para surtos de dengue, febre amarela, chicungunha e esquistossomose na cidade, além do agravamento de doenças crônicas em virtude do estresse pós traumático naturalmente experimentado entre os brumadinhenses, entre elas a hipertensão e a diabetes, podendo surgir ainda outras moléstias como problemas respiratórios e cardiovasculares, acidentes domésticos, ansiedade e até mesmo depressão, que, inclusive, já levou uma pessoa a cometer suicídio logo após o rompimento da barragem (CASTRO, 2019).

Tais consequências lastimáveis estão apenas começando. Segundo os aludidos especialistas, além dos reflexos imediatos, muitos malefícios oriundos da tragédia poderão se manifestar após décadas, o que impõe uma atenção redobrada à saúde desse povo, que carregará os impactos psicológicos da catástrofe pelo restante da vida (BASTOS; ELLER, 2019). Todos esses danos e violações são sequelas de uma exploração desmedida que a atividade minerária desempenha no local antes mesmo da fundação da cidade.

Brumadinho "nasceu do minério". A cidade, que atualmente conta com 81 anos de existência e ainda encontra na mineração sua principal fonte de renda, teve sua origem com a construção do Ramal do Paraopeba da Estrada de Ferro Central do Brasil, que, por sua vez, só foi desenvolvido para transportar os grandes depósitos de minério de ferro descobertos em suas terras, mais precisamente, a quarta posição em relação a todas as reservas de minério do país (JARDIM; JARDIM, 1982).

Com a chegada de trabalhadores para a construção do ramal e para a extração do minério formou-se e desenvolveu-se o povoado, mas o preço desse desenvolvimento ofertado pelo capital foi alto demais.

Esse é o sistema capitalista e as várias facetas de sua engrenagem, que concedem migalhas para, em troca, colocar em risco a própria vida dos "beneficiados".

De fato, a presença da Vale S.A. na região gerou inúmeros empregos, fomentou o co- 
mércio e contribuiu substancialmente com o Estado. A concessão de planos educacionais e de saúde a seus empregados era o instrumento determinante a criar nos indivíduos o desejo de trabalhar na instituição, mas não porque se tratava de uma empresa efetivamente boa de se trabalhar e sim por uma questão de necessidade. Necessidade de conceder à família tratamento adequado de saúde em contraponto às ausências e a morosidade do SUS, necessidade de estudar, de crescer profissionalmente e garantir o mesmo crescimento aos filhos, quando o sistema estatal é fortemente defeituoso e corrupto, necessidade, porque não havia outra fonte de emprego na cidade e era preciso prover a sua própria subsistência.

E foi assim que, movidas pela premente necessidade, inúmeras vidas foram tolhidas, reflexo de uma redução de custos irresponsável e gananciosa.

Destarte, documentos demonstram que a mineradora estava ciente de riscos na barragem. O método a montante é o mais barato, mas também o mais frágil e inseguro, pois usa como barreira o próprio rejeito e não uma estrutura de concreto. Os piezômetros já não faziam a leitura da pressão interna de água e a última leitura que havia sido feita foi tão alarmante que os responsáveis imaginaram que estavam dissonantes e estragados. A barragem não continha dreno de fundo, outro dreno responsável por tirar a água da barragem estava seco e os restantes com trincas, o que poderia por si só ocasionar a liquefação ${ }^{3}$ e o rompimento da estrutura em sua base a qualquer momento. Não fosse o bastante, havia ainda uma nascente mal canalizada desaguando na barragem. A inspeção apontou erosão e problemas de drenagem, mas o laudo foi emitido mesmo assim. O pior aconteceu, a sirene de emergência que poderia ter salvado inúmeras vidas não tocou, apesar de existir tecnologia suficiente para acionar esse tipo de sinal mesmo na iminência de catástrofes, mas que obviamente não fora escolhida, posto que mais cara (FERREIRA; PORTO, 2019).

Observa-se, pois, que a tragédia em análise poderia ter sido evitada se a empresa responsável tivesse cumprido devidamente com suas obrigações de manutenção e segurança, mas o que se viu foi um extremo apreço por questões monetárias em detrimento das pessoas.

O resultado? Uma cidade inteira destroçada.

Trabalhadores sobreviventes já se preocupam com o futuro desemprego, que certamente virá, tão logo os holofotes se desviem da empresa. Outros, sequer conseguem trabalhar depois de terem visto vários amigos sucumbirem à lama. Demais moradores temem o que acontecerá tão logo a cidade caia no esquecimento e desde já sofrem com o aumento dos preços de todas as mercadorias na cidade em razão do crescimento da demanda com a chegada de pessoal de apoio, momento em que o capital mais uma vez mostra a sua face mais perversa.

Hoje, a única certeza que se tem é que essa tragédia constitui um incontestável alerta de uma tendência altamente destrutiva que por muito tempo fora mascarada por um sistema que zela apenas pelos interesses egoísticos das elites.

Estaremos, nós, atentos para aprender com essa advertência?

Com parcas indenizações, o capital busca encobrir o caso e novamente se apresentar como um grande benfeitor social. Mas será que míseros valores efetivamente compensam famílias inteiras dizimadas? Vidas, futuros, sonhos e a alegria no rosto de toda uma população que se perdeu? Afinal, teria a vida um preço?

Fenômeno em que o estado sólido torna-se líquido (FERREIRA, 2018). 


\section{RESPONSABILIDADE CIVIL E A SUPERAÇÃO DA CULPA}

A fixação do conceito jurídico da responsabilidade civil envolve a investigação da evolução do instituto, assim como a busca do significado clássico do termo responsabilidade.

Émile Benveniste (apud TUPONI JUNIOR, 2008) esclarece que o berço da palavra responsabilidade reside no verbo latino spondeo, que, juridicamente, pode ser interpretado como garantir legalmente, dar sua caução pessoal.

De spondeo surge também a palavra latina respondere, necessidade de responder a alguma coisa, ou seja, de responsabilizar pelo dano causado a outrem. Significa a "obrigação que tem alguém de assumir com as consequências jurídicas de sua atividade" (GAGLIANO; PAMPLONA FILHO, 2011, p. 2), onde a imposição social de conferir a todos o dever de responder por seus atos pode ser traduzida, de acordo com Stoco (2001), como a própria noção de Justiça.

Embora o termo responsabilidade possa ser conceituado de diferentes maneiras, como se viu das lições doutrinárias citadas, Zanobi (apud STOCO, 2001) assevera que não deve haver dúvidas de que o termo "responsabilidade" serve para indicar aquela situação em que alguém deva arcar com as consequências de um fato danoso.

O fundamento da responsabilidade civil reside no livre-arbítrio conferido aos homens que convivem em uma sociedade democrática de direito. Diante das opções de conduta há aquelas lesivas a terceiros, instaurando "o princípio geral de direito de que a ninguém é permitido prejudicar outrem, consubstanciado pela máxima romana neminem laedere, também chamada alterum non laedere" (DALLEGRAVE NETO, 2007, p. 98).

A responsabilidade civil é, então, em sua concepção tradicional, a obrigação que pode incumbir a uma pessoa a reparar o prejuízo causado a outra, por fato próprio ou por fato de pessoas ou coisas de que dela dependam, visando coibir o mau uso das liberdades individuais, relacionando-se "[...] à liberdade e à racionalidade humanas, que impõem à pessoa $o$ dever de assumir os ônus correspondentes a fatos a ela referentes" (BITTAR, 2005, p. 2).

A responsabilidade não é fenômeno exclusivo da vida jurídica, ligando-se a todos os domínios da vida social.

Para que surja o dever de indenizar devem estar presentes todos os elementos que compõem a estrutura da responsabilidade civil. A enumeração desses pressupostos, porém, não é assunto pacificado na doutrina.

Enquanto Agostinho Alvim (1972) considera como pressupostos o prejuízo, a culpa e o nexo causal; Silvio Rodrigues (2003) indica a ação ou omissão do agente, a culpa do agente, a relação de causalidade e o dano experimentado pela vítima. Por sua vez, tem-se que Fernando Noronha (2007), ao analisar os pressupostos da responsabilidade civil, alude a dano, cabimento do dano no âmbito de proteção de uma norma, fato antijurídico, nexo de causalidade e nexo de imputação.

Neste trabalho, adotaremos como pressupostos da responsabilidade civil a tripartição simplificada - conduta, dano e nexo de causalidade -, por ser esta aplicável a todo e qualquer tipo de responsabilidade civil.

Conduta é "o comportamento humano voluntário que se exterioriza através de uma ação ou omissão, produzindo consequências jurídicas” (CAVALIERI FILHO, 2010, p. 24). Esse conceito abrange os atos comissivos e os omissivos. 
O comportamento do agente pode ser comissivo - quando implica a prática de um ato pelo sujeito que deveria abster-se de praticá-lo - ou omissivo - caracterizado pela abstenção de uma conduta que deveria ser realizada pelo sujeito. Em regra, a ausência de conduta não tem o condão de ocasionar um dano, porém, tem-se entendido que a omissão pode ter relevância jurídica em algumas situações:

[...] tem-se entendido que a omissão adquire relevância jurídica, e torna o omitente responsável, quando este tem dever jurídico de agir, de praticar um ato para impedir o resultado, dever, esse, que pode advir da lei, do negócio jurídico ou de uma conduta anterior do próprio omitente, criando o risco da ocorrência do resultado, devendo, por isso, agir para impedi-lo (CAVALIERI FILHO, 2010, p. 24).

A vontade, aspecto psicológico ou subjetivo da conduta, é, nas palavras de Gagliano e Pamplona Filho, o núcleo fundamental, "que resulta exatamente da liberdade de escolha do agente imputável, com discernimento necessário para ter consciência daquilo que faz" (GAGLIANO; PAMPLONA FILHO. 2011, p. 69).

Sendo assim, a conduta só adquire relevância jurídica se é proveniente de uma ação voluntária; sem a voluntariedade não há que se falar em ação humana, tampouco em responsabilização do agente.

Além disso, a conduta humana não precisa, necessariamente, ser daquele que está obrigado a reparar o dano, podendo a responsabilidade resultar tanto de ato próprio, como de ato de terceiro que esteja sob a guarda do agente.

Nesses casos, há a conduta voluntária do responsabilizado, caracterizada pela omissão em relação aos deveres jurídicos de custódia e vigilância, cuja responsabilização é imposta por lei. Como exemplo, tem-se o artigo 932 do Código Civil, que estatui que os pais respondam pelos filhos menores que estiverem sob seu poder e em sua companhia.

$\mathrm{Na}$ etiologia da responsabilidade civil estão presentes três elementos considerados essenciais: uma conduta humana, um dano e o nexo de causalidade entre os dois elementos anteriores.

Portanto, não basta que haja uma conduta, "não se define a responsabilidade pelo fato de cometer um "erro de conduta" (STOCO, 2001, p. 108); tampouco é suficiente que a vítima sofra um dano. Para que reste configurada a responsabilidade civil, é necessária a relação de causa e efeito entre a ação e/ou omissão do agente e o dano verificado.

A relação de causalidade está caracterizada no verbo "causar" presente na redação do artigo 186 do Código Civil e deve ser a primeira questão a ser enfrentada nas situações que envolvam a responsabilidade civil, pois pode haver responsabilidade sem culpa, como visto na responsabilidade objetiva, mas jamais pode haver responsabilidade sem nexo causal entre a conduta ensejadora do dano.

Demogue, citado por Rui Stoco (2001, p. 4), discorre sobre a indispensabilidade do nexo causal, dizendo que: "é preciso esteja certo que, sem este fato, o dano não teria acontecido. Assim, não basta que uma pessoa tenha contravindo a certas regras; é preciso que sem esta contravenção, o dano não ocorreria". Três teorias tentam explicar o nexo de causalidade. A teoria da equivalência de condições; a teoria da causalidade adequada; e a teoria da causalidade direta e adequada. 
Utilizada pela doutrina majoritária, a Teoria da Causalidade Direta ou Imediata defende que causa "seria apenas o antecedente fático que, ligado por um vínculo de necessariedade ao resultado danoso, determinasse esse último como uma consequência sua, direta e imediata" (GAGLIANO; PAMPLONA FILHO, 2011, p. 140). Para essa teoria, só há nexo de causalidade quando o dano é efeito necessário de uma causa, o que sempre envolve o dano direto e imediato, e, às vezes, o dano indireto e remoto.

Em relação ao acidente do trabalho, prevalece a Teoria da Causalidade Direta ou Imediata, ao determinar que o acidente do trabalho possa ter várias causas e que a predisposição genética para certa doença não exclui o requisito do nexo causal quando essa incapacidade é deflagrada no e pelo ambiente de trabalho. De tal modo, mesmo diante da predisposição genética para a doença, caso essa seja agravada em virtude do ambiente de trabalho, caberá uma indenização ao trabalhador.

Tem-se ainda como pressuposto o dano. Estabelecer um conceito para dano, conteúdo do objeto da reparação, é fundamental ao desenvolvimento do tema abordado neste trabalho, pois sem dano não há que se cogitar em responsabilização, tampouco nas funções da indenização. "Pode haver responsabilidade sem culpa, mas não poder haver responsabilidade sem dano" (CAVALIERI FILHO, 2010, p. 70).

O dano pode ser analisado de três modos: como violação a um direito subjetivo, como ofensa a um interesse ou como lesão a um bem jurídico.

$\mathrm{Na}$ primeira hipótese, o dano pode ser entendido como "violação à tutela que o direito dispensa a determinados bens" (BASSAN, 2009, p. 5), ou seja, a transgressão ao direito subjetivo, não sendo relevante o resultado da violação do ato ilícito, mas sim sua mera transgressão.

Aqueles que entendem o dano como ofensas a um interesse classificam-no de acordo com a natureza do interesse atingido, sendo o interesse a "faculdade que tem o titular do direito de atuar sobre determinados bens jurídicos" (BASSAN, 2009, p. 5).

Por último, tem-se o dano como subtração ou diminuição de um bem jurídico, aquele prejuízo decorrente de um ato lesivo aos bens tutelados pelo Direito. Nesse sentido, Sérgio Cavalieri Filho define dano como:

[...] sendo a subtração ou diminuição de um bem jurídico, qualquer que seja a sua natureza, quer se trate de um bem patrimonial, quer se trate de um bem integrante da própria personalidade da vítima, como a sua honra, a imagem, a liberdade etc. Em suma, dano é lesão de um bem jurídico, tanto patrimonial como moral, vindo daí a conhecida divisão do dano em patrimonial e moral (CAVALIERI FILHO, 2010, p. 73).

Outras definições de dano existem e poderiam ser abordadas neste trabalho, porém, as três posições doutrinárias apresentadas mostram-se suficiente para demonstrar sua posição de relevância no instituto da responsabilidade civil, constituindo o dano o seu elemento preponderante.

Quanto a sua espécie, a classificação mais conhecida é aquela que divide o dano em patrimonial (material) ou moral. 
Patrimônio "é o conjunto das relações jurídicas de uma pessoa, apreciáveis em dinheiro" (GONÇALVES, 2012, p. 529). Sendo assim, o dano material é aquele que atinge os bens integrantes do patrimônio da vítima, causando sua diminuição efetiva. É suscetível de avaliação pecuniária, podendo, quase sempre, ser reparado diretamente, ou, pelo menos, de maneira indireta, por intermédio de uma indenização ou outro meio equivalente.

Indenizar significa reparar o dano causado a alguém em toda a sua extensão, devendo abranger aquilo que efetivamente se perdeu - dano emergente - e aquilo que se deixou de lucrar - lucro cessante.

Até aqui discorremos sobre o dano patrimonial, porém, como já mencionado, o dano também pode atingir direitos sem conteúdo pecuniário. A distinção do dano em patrimonial e em não patrimonial não se refere ao dano em sua origem, mas em seus efeitos, haja vista que uma causa moral pode causar prejuízos materiais, enquanto causas materiais também podem originar danos morais (LOPEZ, 1999). A reparação do dano moral pode ocorrer autonomamente ou em conjunto com o dano material.

Fazendo uma breve distinção entre patrimônio moral e material, Arnaldo Marmitt conceitua que o primeiro é formado de bens ideais, ao passo que o patrimônio material é constituído de bens conversíveis em dinheiro (MARMITT,1999). O autor também afirma que o patrimônio moral se extingue com a morte de seu titular, não sendo em regra transmissível, enquanto o material sobrevive a seu dono.

Sem o objetivo de adentrar profundamente ao tema, podemos afirmar que o "dano moral é aquele que lesiona a esfera personalíssima da pessoa (seus direitos da personalidade), violando, por exemplo, sua intimidade, vida privada, honra e imagem, bens jurídicos tutelados constitucionalmente" (GAGLIANO; PAMPLONA FILHO, 2011, p. 55).

Abrangendo também o nome, o conceito social e a privacidade da pessoa jurídica, o dano moral "é aquele que, direta ou indiretamente, a pessoa física, bem assim a coletividade, sofre no aspecto não econômico de seus bens jurídicos" (FRANÇA apud MARMITT, 1999, p. 31). Os tribunais têm adotado entendimento de que não há qualquer razão para excluir das pessoas jurídicas o direito de "reclamar o ressarcimento dos prejuízos suportados no plano do nome comercial, do seu conceito na praça, do sigilo de seus negócios etc." (THEODORO JUNIOR, 2001, p. 11).

Situação interessante é também a do nascituro, em que os Tribunais têm entendido que a perda de seus genitores pode gerar uma adequada indenização, quando a morte destes tenha sido culposamente provocada por seus empregadores. Salienta-se que a indenização está condicionada ao seu nascimento com vida.

A violação aos direitos da personalidade constitui em agressão à moral do indivíduo, gerando o direito à reparação; direito esse que prescinde da comprovação, cabal do dano, bastando à vítima demonstrar o fato e a lesão, ficando o dano moral evidenciado.

Teresa Ancona Lopez (1999) afirma que dependendo do bem jurídico ou dos aspectos da personalidade atingidos, os danos morais podem ser distintos entre si, podendo assumir a forma objetiva ou subjetiva. Para a autora, o dano moral objetivo é "aquele que atinge a dimensão moral da pessoa no meio social em que vive, envolvendo o de sua imagem" (LOPEZ,1999, p. 24), enquanto o dano moral subjetivo "se correlaciona com o mal sofrido pela pessoa em sua subjetividade, em sua intimidade psíquica” (LOPEZ,1999, p. 25). 
Embora distintos, o dano moral objetivo também pode ser acompanhado do sofrimento de ordem psíquica.

No tocante à reparação do dano moral, este também se diferencia do dano material, dada a impossibilidade de reposição ao statu quo ante, sendo possível apenas uma reparação compensatória em dinheiro. Enquanto no dano material é possível a recomposição do patrimônio, a indenização por danos morais serve como uma compensação aos dissabores (MARMITT, 1999).

Cumpre mencionar que a Consolidação das Leis do Trabalho alude ao dano em três diferentes artigos. O primeiro deles, artigo 161, apresenta uma hipótese de responsabilidade objetiva diante do risco da atividade, dispondo sobre a possibilidade de interdição do estabelecimento empresarial caso reste demonstrado grave e iminente risco para o trabalhador, completando o $\S 4^{\circ}$., do mesmo dispositivo, que responderá por desobediência àquele que descumprir a ordem, vindo a causar danos a terceiros:

\begin{abstract}
Artigo 161 - O Delegado Regional do Trabalho, à vista do laudo técnico do serviço competente que demonstre grave e iminente risco para o trabalhador, poderá interditar estabelecimento, setor de serviço, máquina ou equipamento, ou embargar obra, indicando na decisão, tomada com a brevidade que a ocorrência exigir, as providências que deverão ser adotadas para prevenção de infortúnios de trabalho.

$\S 4^{\circ}$. - Responderá por desobediência, além das medidas penais cabíveis, quem, após determinada a interdição ou embargo, ordenar ou permitir o funcionamento do estabelecimento ou de um dos seus setores, a utilização de máquina ou equipamento, ou o prosseguimento de obra, se, em consequência, resultarem danos a terceiros (BRASIL, 1943).
\end{abstract}

O artigo 166, por sua vez, ao tratar do fornecimento, pelos empregadores, de Equipamento de Proteção Individual (EPI) aos trabalhadores, de forma gratuita e "sempre que as medidas de ordem geral não ofereçam completa proteção contra os riscos de acidentes e danos à saúde dos empregados", estabelece uma hipótese de responsabilidade subjetiva, havendo a responsabilização do empregador que não fornecer EPI ou que o fornecer de maneira inadequada, não compatível com o risco ao que o trabalhador se encontra exposto.

Por último, tem-se o artigo 462, que demonstra a possibilidade de descontos do salário do empregado caso ele seja o autor de algum dano, estatuindo que o mesmo só seja possível em caso de prévio acordo entre as partes ou de dolo do empregado:

\footnotetext{
Artigo 462 - Ao empregador é vedado efetuar qualquer desconto nos salários do empregado, salvo quando este resultar de adiantamentos, de dispositivos de lei ou de contrato coletivo.

$\S 1^{\circ}$. - Em caso de dano causado pelo empregado, o desconto será lícito, desde de que esta possibilidade tenha sido acordada ou na ocorrência de dolo do empregado (BRASIL, 1943).
}

A CLT, nos artigos citados, aborda tanto o dano material quanto o dano moral. Os danos advindos dos artigos 161 e 166 da CLT podem afetar tanto a esfera patrimonial do trabalhador quanto a sua esfera moral. Já o artigo 462 se refere exclusivamente ao 
dano material que o trabalhador, no exercício de sua função laboral, possa causar ao seu empregador.

A teoria tradicional da responsabilidade civil, que é a subjetiva, tem a culpa como pressuposto essencial do dever de reparar o dano causado a outrem.

A culpa era, então, elemento fundamental para a construção de toda a teoria da responsabilidade civil clássica, sua "pedra de toque", só sendo responsabilizado aquele que, ao fazer mau uso de sua liberdade individual, do seu livre-arbítrio, atuasse de forma culposa.

A responsabilidade civil subjetiva é, portanto, a decorrente do dano causado em função de um ato doloso ou culposo. Ato doloso seria aquele em que o agente possui a intenção de causar o dano; já no ato culposo a intenção não existe, mas o ofensor, ao atuar com negligência ou imprudência, assume os riscos de sua ocorrência.

Os inconvenientes da teoria da responsabilidade civil subjetiva, entre eles a complicada definição de culpa - seu elemento principal - e a dificuldade de sua prova por parte do lesado - já que caberá ao autor do pedido de reparação de danos o ônus da prova da culpabilidade do réu, por se caracterizar a culpa fato constitutivo do direito à pretensão reparatória - levou à construção da teoria objetiva.

A superação do modelo unicamente pautado na responsabilidade subjetiva decorre do número crescente de danos que, em face da exigência de comprovação da culpa, restavam sem a devida reparação. Outro marco relevante na expansão da responsabilidade civil foi a Revolução Industrial que, com a introdução das máquinas nos ambientes laborais, trouxe a dificuldade em identificar uma culpa na origem do dano, e, até mesmo, o causador do dano (VAZ, 2009).

Como forma de resolver os casos em que não se identificava culpa por parte dos protagonistas, surge o fenômeno da objetivação, que consiste no progressivo distanciamento do princípio segundo o qual não pode haver responsabilidade sem culpa. Assim como na teoria clássica da responsabilidade civil, os elementos conduta humana, dano e nexo causal são essenciais à sua configuração, dispensando-se, unicamente, o elemento culpa, que passa a ser irrelevante para a configuração do dever de indenizar.

A responsabilidade objetiva funda-se no risco, ou seja, "na probabilidade de dano, importando, isso, dizer que aquele que exerce uma atividade perigosa deve-lhe assumir os riscos e reparar o dano dela decorrente" (CAVALIERI FILHO, 2010, p. 142). Embora, como regra, essa modalidade vise à reparação dos danos causados por atividades perigosas, ocasionadas por acidentes de consumo, danos resultantes da poluição ambiental, entre outros; a responsabilidade objetiva traz em seu conteúdo diferentes enfoques, merecendo destaque as teorias do risco-proveito, risco-criado e a ideia de garantia.

A teoria do risco-proveito determina que é responsável aquele que se beneficia da atividade danosa, com base no princípio de que, onde está o ganho, aí reside o encargo (CAVALIERI FILHO, 2010). O artigo 933 do Código Civil de 2002 introduziu uma solidariedade entre as pessoas, responsabilizadas pelos danos causados por terceiros e estes próprios, analisando Giselda Hironaka tratar-se "[...] da tão ansiada transição da culpa presumida e do ônus probatório invertido para uma objetivação efetiva desta responsabilidade in casu" (HIRONAKA, 2005, p. 585).

$\mathrm{O}$ princípio da responsabilidade pelo risco-proveito se aplica às relações de emprego, sendo esse o sentido do artigo $2^{\circ}$. da CLT, quando faz menção à assunção do risco pelo empregador em relação aos riscos da atividade econômica. 
As críticas a essa teoria, que tem a dificuldade em delimitar seu alcance, havendo a dúvida se o proveito aplicável é amplo ou somente de natureza econômica, levaram os objetivistas a criar a teoria seguinte, do risco-criado.

Pela teoria do risco-criado, Caio Mário da Silva Pereira entende que "aquele que, em razão de sua atividade ou profissão, cria um perigo, está sujeito à reparação do dano que causar, salvo prova de haver adotado todas as medidas idôneas a evitá-lo" (PEREIRA, 2001 , p. 24). Por essa teoria, tem-se que aquele que desenvolve atividades lícitas, mas perigosas para a sociedade, deve assumir os riscos.

A teoria do risco-criado foi adotada pelo Código Civil de 2002, no parágrafo único do artigo 927, e beneficiou a vítima, no sentido que a isentou de comprovar qualquer tipo de vantagem ou proveito obtido pelo agente (PEREIRA, 2001).

Em terceiro, tem-se a Teoria do Risco-Profissional, mais ampla que a anterior, pois se estende a todos os empregadores e não somente àqueles que exercem atividades perigosas. José Affonso Dallegrave Neto entende que essa teoria limitasse à reparação acidentária, já que, "independentemente de culpa o empregador se responsabiliza pelos danos oriundos de acidentes de trabalho de seus empregados, mediante o custeio de seguro específico. Trata-se do SAT: Seguro de Acidente do Trabalho" (DALLEGRAVE NETO, 2009, p. 50).

Importante perceber que a culpa pode ou não existir, mas será sempre irrelevante para a configuração do dever de indenizar (GONÇALVES, 2012). Assim, ao não impor à vítima a prova da culpabilidade do ofensor, muitas vezes vista como prova diabólica, a responsabilidade objetiva traz também um benefício ao judiciário, analisando Daniel Pinto de Carvalho que os processos se tornam, além de mais céleres, menos custosos (CARVALHO, 2012).

Sem abandonar a responsabilidade subjetiva, mas ampliando os domínios da teoria objetiva, o Código Civil Brasileiro de 2002 adota as mudanças que já eram absorvidas por outros ordenamentos jurídicos alienígenas, ao incluir a teoria do risco no parágrafo único do artigo 927: "Haverá obrigação de reparar o dano, independentemente de culpa, nos casos especificados em lei, ou quando a atividade normalmente desenvolvida pelo autor do dano implicar, por sua natureza, risco para os direitos de outrem" (BRASIL, 2002).

Essa teoria, porém, não pode ser vista de forma irrestrita, pois toda atividade implica um risco a terceiros, mesmo que mínimo. Para que seja adotada a teoria do risco é imprescindível que na natureza da atividade exista uma potencialidade lesiva fora dos padrões normais, que o risco seja inerente, intrínseco à atividade, como ocorre com a Mineradora Vale. Ressalta-se que a aplicabilidade de uma responsabilidade objetiva e coletiva, amparada pelo aspecto da solidariedade inerente aos direitos da terceira dimensão (VAZ, 2009), não significa o desaparecimento da responsabilidade subjetiva e individual, permanecendo esta regra.

\section{RESPONSABILIDADE TRABALHISTA}

A relação trabalhista é essencialmente desigual, "sendo campo fértil para situações que contrariam preceitos de ordem pública como os consagrados direitos da personalidade" (SILVA; BEZERRA, 2008, p. 3); direitos esses tidos pela doutrina como absolutos, cujo 
objeto está na própria pessoa do titular e aos quais correspondem deveres jurídicos de todos os membros da sociedade.

O contrato individual de trabalho, por posicionar seus sujeitos em níveis visivelmente desnivelados, tendo em vista a superioridade econômica do empregador e o estado de sujeição do empregado, é propício ao exercício abusivo de direitos, revelando-se o poder de comando do empregador e a dependência econômica do empregado fontes muito ativas de ilicitude e de ofensa ao patrimônio, frequentemente moral, do trabalhador (PINTO, 2005).

A relação de poder inerente aos contratos trabalhistas torna a esfera laboral propícia à ocorrência de danos, sendo que de todos os ramos do direito é no âmbito trabalhista que se verificam, com frequência, os mais variados tipos de lesão à dignidade do trabalhador. Embora a tutela ao direito da personalidade se estenda a todos, de maneira igual, seja ou não trabalhador, na esfera trabalhista, a proteção aos direitos personalíssimos assume uma ampla importância, carecendo o trabalhador, nos dias correntes, da tutela jurídica, "a fim de equilibrar a relação de emprego em face da hegemonia econômica da empresa" (DALLEGRAVE NETO, 2009, p. 61).

Ressalta-se que o empregado, ao celebrar um contrato de trabalho, não assume qualquer risco, tendo o direito de permanecer incólume em seu patrimônio físico, moral e econômico: "Desse modo, qualquer dano corporal, moral ou financeiro ocorrido em razão da atividade profissional, fará com que a indenização recaia sobre aquele que detém o risco da atividade: a empresa empregadora" (DALLEGRAVE NETO, 2009, p. 305).

$\mathrm{O}$ instituto da responsabilidade civil encontra-se atrelado à culpa do agente, tendo que, por via de regra, a responsabilidade é do tipo subjetiva. Nos termos do artigo $7^{\circ}$., XXVIII, da Constituição Federal, para que haja as indenizações por acidente de trabalho ou doença ocupacional faz-se necessária a presença de dolo ou culpa por parte do empregador. Dallegrave Neto demonstra que a culpa patronal pode ser caracterizada de duas formas:

\footnotetext{
a) Culpa por violação à norma legal; aqui incluindo-se as normas da Constituição Federal, da CLT, dos instrumentos normativos da categoria e as Normas Regulamentadoras do Ministério do Trabalho e Emprego.

b) Culpa por violação ao dever geral de cautela; aqui se incluindo os deveres de prevenção e precaução (DALLEGRAVE NETO, 2009, p. 257).
}

A empresa tem o dever legal de adotar as medidas preventivas cabíveis para afastar os riscos inerentes ao trabalho, possuindo o empregado o direito constitucional de laborar em um ambiente onde as normas de higiene, medicina e segurança do trabalho são cumpridas. É dever do empregador a proteção ao patrimônio físico, psicológico e moral do trabalho, devendo zelar pela saúde dos seus empregados através da adoção do dever geral de cautela, que preconiza os princípios da prevenção e precaução.

Assim, ao ser contratado, o trabalhador traz consigo alguns direitos fundamentais, como: a vida e a integridade física e moral, que devem ser protegidas pelo patrão. A indenização acidentária, por sua vez, tem como princípio basilar o restitutio in integrum, visando reparar todos os prejuízos causados pelo empregador em virtude do acidente de trabalho. Tem lugar somente na ilicitude patronal, ou no caso de risco previsível em atividade normal 
(responsabilidade objetiva), e seu valor deve assegurar que a vítima mantenha o padrão de vida que possuía antes da ocorrência do dano.

Por tratar-se de institutos diferentes, com objetivos distintos, o Enunciado $n^{\circ}$. 48, proferido na I Jornada de Direito do Trabalho, dispõe: “A indenização decorrente de acidente de trabalho ou doença ocupacional, fixada por pensionamento ou arbitrada para ser paga de uma só vez, não pode ser compensada com qualquer benefício pago pela Previdência Social”.

Como já exposto, com o advento do novo Código Civil em 2002, o sistema normativo passou a contar com a previsão legal de responsabilidade civil objetiva, no caso em tela, havendo o acidente de trabalho, ou equiparável, e relação entre este e o trabalho exercido, será o empregador obrigado a indenizar quando a atividade normalmente desenvolvida implicar riscos para os direitos de outrem.

Cléber Lúcio de Almeida (2003) chama a atenção para o fato de que não se trata do risco relacionado à atividade preponderante do empregador, mas sim do risco presente em cada setor de sua atividade total.

Aquele que se beneficia com a atividade que expõe o trabalhador a riscos superiores aos enfrentados pelo "homem médio", auferindo seus lucros, deve suportar integralmente os riscos advindos desta, devendo indenizar seus danos, independentemente de culpa.

Embora o Brasil possua uma das legislações mais completas e avançadas em matéria de saúde do trabalhador, o país é recordista mundial em acidentes do trabalho, com três mortes a cada duas horas e três acidentes não fatais a cada um minuto. Esse paradoxo demonstra que o cerne do problema não está no Legislativo, mas sim na ausência de fiscalização e na "cultura empresarial mercantil e imediatista que se nega a investir em prevenção de acidentes, tratando com total menoscabo a legislação infortunística" (DALLEGRAVE NETO, 2009, p. 4).

Tem-se assim a denominada Síndrome do Descumprimento das Obrigações Trabalhistas, em que o empregador calcula o que é mais vantajoso economicamente cumprir: a legislação vigente ou infringir as leis e arcar com a indenização dos poucos trabalhadores que procuram a Justiça do Trabalho.

A constitucionalização da responsabilidade civil, através do princípio da dignidade humana, coloca o ser humano em posição de relevância, não podendo este sofrer quaisquer tipos de agressão quando em ambiente laboral. O princípio da livre iniciativa, também preconizado pela Constituição, não pode se sobrepor aos princípios da dignidade, dos valores sociais do trabalho e da defesa do meio ambiente.

$\mathrm{O}$ acidente do trabalho pode gerar danos materiais, morais, estéticos e até mesmo existenciais ao trabalhador, estando intimamente relacionado com a vida deste. Desse modo, o dano que resulta do acidente deve ser punido de modo especial como forma de evitar sua incidência.

\section{QUANTO VALE A VIDA?}

Nos últimos anos, trabalhadores e trabalhadoras têm sido vítimas de enormes ataques desferidos pelo capital e pelos mais diversos agentes públicos sem que isso, no entanto, tenha sido percebido como tal. A "reforma" trabalhista, amparada por um discurso econômi- 
co voltado à proteção dos interesses de grandes empresas, bem ao contrário do tratamento conferido às vítimas da Vale em Brumadinho pela mídia e pela sociedade em geral, restou por rebaixar a sua condição de cidadania pelo simples fato de se enquadrarem na qualidade de trabalhadores e trabalhadoras que ostentam uma relação de emprego, uma vez que, com relação a todas as demais vítimas do mesmo evento a reparação pelos inestimáveis danos extrapatrimoniais deve ser integral (art. 944 do Código Civil). Já com relação aos empregados, por determinação dos artigos 223-A a 223-G, introduzidos na CLT pela lei da "reforma", as indenizações por danos morais não poderão exceder a, no máximo, cinquenta vezes os seus salários, sem possibilidade de cumulação, além da absurda utilização do salário de cada empregado como sistemática de cálculo para fixação do montante indenizatório, o que evidencia flagrante discriminação contemplada na reforma, que passa a medir a condição humana através da renda (SOUTO MAIOR, 2019).

Diante de tamanha distorção, conforme assevera Jorge Luiz Souto Maior (2019), é possível até se imaginar a situação grotesca, mas reveladora das contradições e encruzilhadas jurídicas trazidas pela reforma trabalhista, a ponto de a Vale do Rio Doce procurar buscar a declaração de que todas as pessoas acidentadas eram seus empregados, inclusive civis e outros trabalhadores autônomos que lhe prestavam serviços, pois, assim, as indenizações devidas seriam sensivelmente reduzidas.

A discriminação é óbvia, a Constituição Federal em seu artigo $5^{\circ}$., caput, dispõe que "Todos são iguais perante a lei, sem distinção de qualquer natureza [...]" (BRASIL, 2016). Ora, partindo desse pressuposto, não se pode admitir que não empregados recebam indenização substancialmente superior às dos obreiros quando ambos foram vítimas do mesmo ato ilícito, sob pena de grave violação ao texto constitucional.

Seria por acaso a dor dos herdeiros de um morador morto do Parque da Cachoeira, comunidade vizinha às dependências da Vale. S.A, maior que a dor dos herdeiros de um trabalhador que durante a sua árdua labuta morreu? Certamente não.

Ademais, se o Código Civil não prevê qualquer forma de tarifação de danos extrapatrimoniais no título de responsabilidade civil, não há qualquer sentido que haja tal previsão na legislação trabalhista, mormente ante os princípios protetivos do Direito do Trabalho, necessários diante da hipossuficiência de uma das partes litigantes. Com efeito, colocar o trabalhador em uma situação pior do que os demais credores é uma verdadeira aberração, que compromete não apenas os fundamentos basilares do Estado Democrático de Direito, como também a mais elementar noção de unidade e coerência que se espera do ordenamento jurídico como um todo (LAGO, 2018).

Ainda assim, as incoerências da reforma trabalhista não param por aí. Insatisfeitos em estabelecer segregação "tão só" entre trabalhadores e outros civis, os legisladores da reforma trataram ainda de criar discriminação entre os próprios empregados ao estabelecer o salário como base de cálculo de tarifação.

A partir de então, caso dois empregados venham a sofrer o mesmo acidente de trabalho, com os mesmos danos, aquele que detiver uma maior remuneração passará a fazer jus a uma indenização superior se comparada a do outro. Em outras palavras, a reforma considera o dano sofrido por quem tem maior salário superior ao dano sofrido por quem tem salário inferior, o que mostra o ideal iníquo da nova lei. Afinal, não é possível conferir às 
pessoas que foram vítimas do mesmo evento danoso valoração diversa de seu sofrimento. A dor psíquica experimentada por um mecânico não é menor do que a dor experimentada por uma médica.

Nesse sentido, sábia é a observação de Cássio Casagrande (2017, p. 8), para quem:

\begin{abstract}
No caso da regulamentação do dano moral na Reforma Trabalhista, a lei claramente dá um tratamento diferente para pessoas que estão sob a mesma condição de fato e de direito, estabelecendo o seguinte: quem ganhar salário menor, terá reparação menor, ou em outros termos, terá "proteção da lei" em menor grau. Ou então, seria mais preciso dizer, "não terá igual proteção da lei". Isto nada mais é do que uma forma de segregação. Não é uma segregação pela raça, cor, gênero ou nacionalidade: é uma segregação pela renda, pois quanto mais pobre o trabalhador, menor a reparação a ele devida. Os trabalhadores são "iguais" em seus direitos à reparação extrapatrimonial, mas "separados" - por faixa de renda - na hora de distribuição da justiça.
\end{abstract}

Posto em evidência tamanha antinomia, não se pode de maneira alguma admitir como válido o postulado de que a dignidade da pessoa humana decorra de seu "pertencimento" ao mercado de trabalho e, pior ainda, de que a dignidade de determinada pessoa seja tanto menor quanto menos ela receba, quanto mais, quando sabido que o salário é irrelevante para mensurar a dor psíquica que envolve o dano moral. Caso contrário, se contrariaria o imperativo categórico kantiano, crucial na definição dos direitos humanos segundo o qual todos os homens são dignos de igual consideração e respeito, além de violar, novamente, o princípio constitucional da isonomia, que obviamente contempla a igual proteção das leis. $\mathrm{O}$ direito deve proteger a todos de maneira uniforme. A lei não pode criar distinções não justificadas entre os destinatários da norma (CASAGRANDE, 2017).

Além disso, a nossa Constituição estabelece em seu artigo $5^{\circ}$., inciso V, que o direito de resposta deve ser proporcional ao agravo. Portanto, a utilização do salário do empregado como base para a fixação do quantum devido certamente viola os princípios constitucionais da proporcionalidade e da razoabilidade, já que direciona a indenização a uma soma de valores irrisórios. A título de exemplo, a família de um trabalhador que morreu na tragédia de Brumadinho, e que percebia apenas um salário mínimo não fará jus a receber mais que $\mathrm{R} \$ 49.900,00$ (quarenta e nove mil e novecentos reais), valor esse totalmente insignificante considerando a extensão do dano, qual seja, a perda de uma vida, e a capacidade econômica da empresa, que sem dúvidas não se sentirá punida, o que acaba por incentivar, ainda que colateralmente, que novos acidentes por negligência ocorram, já que o caráter punitivo educador da indenização não foi alcançado.

Como assinala Caio Mário da Silva (2001, p. 317):

Na reparação por dano moral estão conjugados dois motivos, ou duas concausas: I) punição ao infrator pelo fato de haver ofendido um bem jurídico da vítima, posto que imaterial; II) pôr nas mãos do ofendido uma soma que não é pretium doloris, porém o meio de lhe oferecer a oportunidade de conseguir uma satisfação de qualquer espécie, seja de ordem intelectual ou moral, seja mesmo de cunho material. 
Isso posto, observa-se que se o artigo 223-G da reforma for efetivamente levado à risca pelo Poder Judiciário, nem o pressuposto punitivo educador nem o pressuposto compensatório, se é que se pode assim dizer, já que valor nenhum é capaz de substituir a vida, serão consagrados, já que míseras indenizações sequer serão sentidas nos cofres da Vale, quanto menos, serão capazes de satisfazer a dor dos familiares das vítimas, cujo sangue clama da lama por justiça.

Nas palavras de Roberto Dala Barba Filho (2017, p. 190):

A intensidade do dano moral grave necessariamente não encontra correspondência no limite máximo tarifado. E, quanto mais estreita esta faixa de reparabilidade, mais avulta a desconformidade da transgressão praticada com a compensação pecuniária capaz de satisfazê-la. Por isso, o método se nos afigura incapaz de permitir que a dor sofrida seja reparada na devida medida, por uma condigna compensação.

Destarte, não existe como definir em caráter objetivo o que seria uma ofensa moral de natureza "leve", "média" ou "grave", tanto é que a norma nem mesmo as procura fixar, sabendo que isso seria absurdo.

Não fosse o bastante, maiores dificuldades ainda terão os empregados terceirizados em perceber justa indenização, já que a responsabilidade da Vale. S.A., enquanto mera "tomadora" de serviços, seria considerada apenas de forma subsidiária, sendo os valores indenizatórios fixados em conformidade com a capacidade econômica das empresas prestadoras, notadamente débil para arcar com as consequências de eventos como esses (SOUTO MAIOR, 2019).

Assim, mesmo que consigam chegar à reparação, tais trabalhadores e familiares perceberão quantias fixadas em valores bastante aquém daqueles que decorreriam do tamanho da indignação social que ora se manifesta em relação à tragédia, sem mencionar a discrepância de valores devidos a título de indenização entre empregados diretos e terceirizados, caso o salário venha a ser efetivamente utilizado como base de cálculo para a parametrização, pois é de notório conhecimento de todos que os salários de terceirizados são extremamente diminutos se comparados aos salários dos empregados diretos. Além de serem tais indenizações direcionadas a terceiros adimplidas com bastante atraso, ou seja, somente depois de esgotadas todas as tentativas possíveis de se receber das empresas prestadoras. Tem-se, portanto, que a parametrização dos danos extrapatrimoniais e a sua metodologia de cálculo aplicada ao salário trazidas pela novel reforma, além de violar os artigos $1^{\circ}$., III, artigo $5^{\circ}$., caput e inciso e V e artigo $7^{\circ}$., XXXII da Constituição da República, ao estabelecer a vedação de distinção entre trabalho manual, técnico e intelectual, reduzem o valor da vida, da saúde e da integridade física do empregado a uma mera variação de seu contracheque. Tais bens da vida, no entanto, possuem pretensão de universalidade, ou seja, devem ser estendidos a todos os seres humanos pela sua simples condição de pessoa humana, sendo irrelevante, para fins de valoração da indenização por dano moral, a situação socioeconômica do ofendido, até mesmo porque a própria natureza dos direitos extrapatrimoniais reside precisamente na sua absoluta indiferença ao patrimônio do seu titular (BARBA, 2017). 
Diante disso, eventuais decisões proferidas pelo Poder Judiciário destinadas a reparar as vítimas da tragédia da Vale S.A. em Brumadinho com fulcro na redação iníqua do artigo 223-G da reforma estarão mergulhadas na mais profunda irresponsabilidade, pois não passam pelo crivo constitucional.

Espera-se, por conseguinte, que o Poder Judiciário assuma seu mister da forma mais justa e equânime possível, cobrindo o aludido dispositivo da devida hermenêutica constitucional que contempla a dignidade da pessoa humana enquanto eixo central de regulação em contraponto às questões meramente patrimonialistas da reforma. As vítimas precisam ser indenizadas segundo aquilo que efetivamente têm direito, sobretudo, se levarmos em consideração que em se tratando de danos extrapatrimoniais, valoração alguma é capaz de restituir ao statu quo ante à ofensa. Caso contrário, a própria finalidade essencial da pretensão indenizatória restaria frustrada, pois o caráter compensatório não seria alcançado, gerando uma contínua sensação de impunidade não só por parte dos atingidos, como também pela própria empresa, que não se sentiria pressionada a inibir que novas tragédias como essa venham a ocorrer, o que frustra também o caráter punitivo educador do instituto.

Diante disso, caberá ao judiciário evitar que leis desumanas e cruéis, produto de um legislativo viciado, venham à tona, ferindo o que de fato é direito, sob pena de se deflagrar uma grave ameaça à segurança jurídica não só das vítimas, mas também de todos os trabalhadores e trabalhadoras do Brasil.

\section{Considerações finais}

Desde o seu nascedouro, o capitalismo teve enquanto objetivo fundamental a maximização do lucro, a constante acumulação de capital e o contínuo bem-estar de uma classe em especial - a burguesia. Para tanto, não demorou para criar mecanismos e métodos de exploração de seus subordinados, que uma vez despojados dos meios de produção necessários para promover seu sustento se viram completamente sujeitos à opressão, não podendo defender-se, já que a perda do emprego equivaleria à perda de sua própria chance de subsistência, bem como, a de sua família.

Valendo-se de tal necessidade existencial, o capital restou por acionar os seus mais extremos instrumentos de espoliação, de roubo, do logro e, principalmente da extração do último fôlego de trabalho ainda que viesse a custar a própria vida do empregado, que haveria de ser sacrificada desde que em prol da boa e perfeita "rentabilidade".

São as chamadas "violências inocentes", apresentadas como a consequência de uma racionalidade econômica totalmente distorcida que quanto mais implicação pessoal dos assalariados requer em prol do sucesso da empresa, tanto maior insignificância lhes delega, deixando-os totalmente abandonados aos riscos da atividade, já que é demasiadamente caro reduzir os riscos à saúde e segurança do trabalho, quanto mais quando a vida e a dignidade do trabalhador já não interessam face à "supremacia" da empresa.

Os resultados não poderiam ser outros, para além da barbárie inegavelmente empreendida em tempos antigos, hoje, o completo encarniçamento da classe trabalhadora tem se mostrado em proporções ainda maiores. É o caso do rompimento da Barragem I da Mina do 
Córrego Feijão na cidade de Brumadinho, Minas Gerais, onde uma corrente de lama e detritos inundou, matou, feriu e sufocou, de modo brutal, centenas de trabalhadores impedidos de gritar por socorro, soterrados por toneladas e toneladas de uma substância mortífera, produto do descaso, da irresponsabilidade e da ganância, não só da empresa responsável, mas também do Estado, que fazendo malabarismos com a legislação procura satisfazer as elites, justificando e aprovando cada vez mais a opressão.

Obviamente, não seria duvidoso se esperar que as consequências de tamanha mesquinharia seriam arcadas pela parte mais fraca: a classe trabalhadora.

Entre mortos e desaparecidos, são mais de trezentas perdas, além de uma cidade inteira destruída, tanto econômica quanto socialmente.

A intensa repercussão midiática do caso acompanhada da gigantesca indignação nacional, no entanto, restou por "denunciar" em parte as barbaridades do capital, que temeroso em perder sua afirmação social, rapidamente buscou encobrir o acontecido e novamente se apresentar como um grande benfeitor por meio de parcas indenizações. Mas será que míseros valores efetivamente compensam famílias inteiras dizimadas? Vidas, futuros, sonhos e a alegria no rosto de toda uma população que se perdeu? Afinal, teria a vida um preço?

Inegavelmente, valoração alguma pecuniária é capaz de substituir a dor de uma vida que se perdeu, mas, ainda assim, nos últimos anos, o capital, amparado por um poder legislativo altamente tendencioso, tratou de reduzir e parametrizar ainda mais a compensação por danos extrapatrimoniais, sobretudo com mecanismos extremamente discriminatórios.

Com efeito, os artigos 223-A a 223-G, introduzidos na CLT pela lei da "reforma" restringem as indenizações por danos morais a no máximo cinquenta vezes o salário do trabalhador vitimado, além de utilizar a sua última remuneração enquanto base de cálculo para fixação do montante indenizatório, o que evidencia o ideal iníquo da reforma, que passa a medir a condição e dor humana por intermédio da renda.

A discriminação é óbvia, a Constituição Federal em seu artigo $5^{\circ}$., caput, dispõe que “Todos são iguais perante a lei, sem distinção de qualquer natureza [...]” (BRASIL, 2016). Ora, partindo desse pressuposto, não se pode admitir que não empregados recebam indenização substancialmente superior às dos obreiros quando ambos foram vítimas do mesmo ato ilícito ou mesmo que entre os próprios empregados que venham a sofrer o mesmo acidente, com os mesmos danos, aquele que detenha uma maior remuneração aufira indenização superior à do outro, sob pena de grave violação ao texto constitucional.

Não obstante, a Carta Magna também prevê que o direito de resposta deve ser proporcional ao agravo, portanto, a utilização do salário do empregado como base para a fixação do quantum devido certamente viola os princípios constitucionais da proporcionalidade e da razoabilidade, já que direciona a indenização a uma soma de valores irrisórios, frustrando frequentemente as duas finalidades precípuas da responsabilização civil - a pretensão punitivo educadora e a compensação ao sofredor, o que acaba por incentivar que novos "acidentes" ocorram, já que míseras indenizações sequer são sentidas nos cofres das grandes empresas, quanto menos, são capazes de satisfazer a dor das vítimas e familiares.

Diante disso, resta claro que a parametrização dos danos extrapatrimoniais e a sua metodologia de cálculo aplicada ao salário trazidas pela novel reforma, além de violar os artigos $1^{\circ}$., III, artigo $5^{\circ}$., caput e inciso e V e artigo $7^{\circ}$., XXXII da Constituição da Repúbli- 
ca, ao estabelecer distinção entre trabalho manual, técnico e intelectual, reduzem o valor da vida, da saúde e da integridade física do empregado a uma mera variação de seu contracheque. Tais bens da vida, no entanto, possuem pretensão de universalidade, ou seja, devem ser estendidos a todos os seres humanos pela sua simples condição de pessoa humana, sendo irrelevante, para fins de valoração da indenização por dano moral, a situação socioeconômica do ofendido, até mesmo porque a própria natureza dos direitos extrapatrimoniais reside precisamente na sua absoluta indiferença ao patrimônio do seu titular.

Nesse cenário de atrocidades, uma atuação justa e equânime é o mínimo que se espera do Poder Judiciário para evitar que leis desumanas e cruéis, como o artigo 223-G da CLT sejam aplicadas na prática, em evidente retrocesso para a classe trabalhadora. Tal dispositivo, antes, deve ser interpretado não de uma maneira estritamente legalista e descomprometida com a realidade sócio-histórica, mas sob um viés pós-positivista, que contemple os valores e princípios constitucionais enquanto finalidade essencial para o alcance de uma verdadeira justiça, em especial, a dignidade da pessoa humana, que deve ser considerada enquanto eixo central de toda a regulação.

Somente assim será possível conter a barbárie da ordem tradicional e, quiçá, avançar para outros rumos: valorizando o que até então pouco valor se detém e contribuindo para a repersonalização do próprio direito, tendo em vista sempre a saúde, a integridade e a dignidade humana.

\section{REFERÊNCIAS}

ALMEIDA, Cléber Lúcio. Responsabilidade civil do empregador e acidente de trabalho. Belo Horizonte: Del Rey, 2003.

ALVIM, Agostinho. Da inexecução das obrigações e suas consequências, 2. ed. São Paulo: Saraiva, 1972.

ANDREONI, Manuela. Preços do minério de ferro caem, e as barragens de rejeitos também, $1^{\circ}$. fev. 2019. Disponível em: https://dialogochino.net/21937-brazil-iron-ore-dam-collapse-brumadinho-mariana/?lang=pt-br. Acesso em: 22 abr. 2019.

ARIADNE, Queila; PIZARRO, Ludmila; LAGÔA, Tatiana. Nunca mais... até quando? O maior desastre trabalhista da história do Brasil, 24 fev. 2019. Disponível em: https:// www.otempo.com.br/hotsites/nunca-mais-at\%C3\%A9-quando. Acesso em: 22 abr. 2019.

BARBA, Roberto Dala Filho. A inconstitucionalidade da tarifação da indenização por dano extrapatrimonial no Direito do Trabalho. Revista eletrônica do Tribunal Regional do Trabalho da 9a Região. Curitiba, v. 7, n. 63, 2017. Disponível em: https://juslaboris.tst.jus. br/bitstream/handle/20.500.12178/122554/2017_barba_filho_inconstitucionalidade_tarifacao.pdf?sequence=1\&isAllowed=y. Acesso em: 22 abr. 2019. 
BASTOS, Camila; ELLER, Johanns. Sobreviventes de Brumadinho estão sujeitos a doenças psicológicas e epidemias, 5 fev. 2019. Disponível em: https://oglobo.globo. com/brasil/sobreviventes-de-brumadinho-estao-sujeitos-doencas-psicologicas-epidemias-23430068. Acesso em: 22 abr. 2019.

BASSAN, Marcela Alcazas. As funções da indenização por danos morais e a prevenção de danos futuros, 2009. Dissertação (Mestrado em Direito Civil) - Universidade de São Paulo, Faculdade de Direito, Programa de Pós-Graduação em Direito, São Paulo, 2009.

BITTAR, Carlos Alberto. Responsabilidade civil: teoria \& prática, 5. ed. Rio de Janeiro: Forense Universitária, 2005.

BRASIL. Decreto-Lei $n^{\circ} .5 .452$, de $1^{\circ}$. de maio de 1943. Aprova a Consolidação das Leis do Trabalho. Diário Oficial da União, Brasília, 9 ago. 1943. Disponível em: http://www. planalto.gov.br/ccivil_03/Decreto-Lei/Del5452.htm. Acesso em: 22 abr. 2018.

BRASIL. Constituição da República Federativa do Brasil. In: VADE Mecum Compacto de Direito, 11. ed. São Paulo: Rideel, 2016.

BRIZA, Dulce Helena Rizzardo. Brumadinho: o segundo alerta. Self - Revista do Instituto Junguiano de São Paulo, São Paulo, v. 4, n. 1, 2019. Disponível em: https://self. emnuvens.com.br/self/article/view/77/259. Acesso em: 22 abr. 2019.

CARVALHO, Daniela Pinto. Fixação do quantum indenizatório na responsabilidade civil por perda de uma chance, 2012. Dissertação (Mestrado em Relações Sociais e Novos Direitos) - Universidade Federal da Bahia, Faculdade de Direito, Programa de Pós-Graduação em Direito, Salvador, 2012.

CASAGRANDE, Cássio. A reforma trabalhista e a inconstitucionalidade da tarifação do dano moral com base no salário do empregado. Revista Jurídica da Escola Superior de Advocacia da OAB-PR. Curitiba, v. 2, n. 3, 2017. Disponível em: http://revistajuridica. esa.oabpr.org.br/wp-content/uploads/2017/12/19122017_revista_esa_5_dezembro_5.pdf. Acesso em: 22 abr. 2019.

CASTRO, Regina. Evento apresenta avaliação sobre impactos imediatos do desastre em Brumadinho, 4 fev. 2019. Disponível em: https://portal.fiocruz.br/noticia/evento-apresenta-avaliacao-sobre-impactos-imediatos-do-desastre-em-brumadinho. Acesso em: 22 abr. 2019.

CAVALIERI FILHO, Sérgio. Programa de responsabilidade civil, 9. ed. São Paulo: Atlas, 2010.

DALLEGRAVE NETO, José Afonso. Responsabilidade civil no direito do trabalho, 2. ed. São Paulo: LTr, 2007. 
FERREIRA, Aurélio Buarque de Holanda. Liquefação. In: FERREIRA, Aurélio Buarque de Holanda. Liquefação. Dicionário Aurélio. Disponível em: https://dicionariodoaurelio. com/liquefacao. Acesso em: 22 abr. 2019.

FERREIRA, Sidnei; PORTO, Dora. Sem Palavras. Revista Bioética, Brasília, v. 27, n.1, jan./mar. 2019. Disponível em: http://www.scielo.br/scielo.php?script=sci_arttext\&pi$\mathrm{d}=$ S1983-80422019000100007\&lng=pt\&tlng=pt. Acesso em: 22 abr. 2019.

FONSECA, Marcelo. Da tragédia de Mariana até a de Brumadinho, Vale obteve todas licenças pedidas em MG, 8 mar. 2019. Disponível em: https://www.em.com.br/app/ noticia/gerais/2019/03/08/interna_gerais, 1036166/tragedia-mariana-brumadinho-vale-obteve-licencas-pedidas-minas.shtml?fbclid=IwAR16LVQN6k6pI8FuAjtSBSTg_WLssYNx82RsRtkLW-hJR3qxHfEqmH4xKIc. Acesso em: 22 abr. 2019.

GAGLIANO, Pablo Stolze; PAMPLONA FILHO, Rodolfo. Novo curso de direito civil: responsabilidade civil, 9. ed. São Paulo: Saraiva, 2011.

GALVÃO, Daniel de Faria. Entre Brumadinho e Mariana, o tempo do homem, 29 jan. 2019. Disponível em: http://www.justificando.com/2019/01/29/entre-brumadinho-e-mariana-o-tempo-do-homem/. Acesso em: 22 abr. 2019.

GAULEJAC, Vincent de. Gestão como doença social: ideologia, poder gerencialista e fragmentação social. Trad. Ivo Storniolo. Aparecida: Ideias e Letras, 2007.

GONÇALVES, Carlos Roberto. Responsabilidade civil, 14. ed. São Paulo: Saraiva, 2012.

HIRONAKA, Giselda Maria F. Novaes. Responsabilidade pressuposta. Belo Horizonte: Del Rey, 2005.

HOBSBAWM, Eric. A era das revoluções: 1789-1848. Trad. Maria Tereza Teixeira e Marcus Penchel. Rio de Janeiro: Paz e Terra, 1977.

JARDIM, Décio Lima; JARDIM, Márcio Cunha. História e riquezas do município de Brumadinho. Belo Horizonte: FUMARC, 1982.

LAGO, Fabrício Sá. Da (in)constitucionalidade do novo art. 223-G da nova CLT, 2018, 50s. Monografia (Conclusão do curso) - Universidade Federal do Rio Grande do Sul, Faculdade de Direito, Porto Alegre.

LAUDO de segurança de barragem em Brumadinho apontou erosão e problemas de drenagem. [S.1.]: O Globo, 2019. Disponível em: https://extra.globo.com/noticias/brasil/ laudo-de-seguranca-de-barragem-em-brumadinho-apontou-erosao-problemas-de-drenagem-23429247.html. Acesso em: 22 abr. 2019. 
LOPEZ, Teresa Ancona. O dano estético: responsabilidade civil. São Paulo: Revista dos Tribunais, 1999.

MARMITT, Arnaldo. Dano moral. Rio de Janeiro: AIDE, 1999.

MARX, Karl. O capital. Trad. Rubens Enderle. São Paulo: Boitempo, 2011.

MINING (coal; other mining) sector [S.1.]: ILO, 2019. Disponível em: http://www.ilo.org/ global/industries-and-sectors/mining/lang--en/index.htm. Acesso em: 22 abr. 2019.

NORONHA, Fernando. Direito das obrigações: fundamentos do direito das obrigações introdução à responsabilidade civil, 2. ed. São Paulo: Saraiva, 2007.

OIT um trabalhador morre a cada 15 segundos por acidentes ou doenças relacionadas ao trabalho. [S.1.]: ONU Brasil, 2013. Disponível em: https://nacoesunidas.org/oit-um-trabalhador-morre-a-cada-15-segundos-por-acidentes-ou-doencas-relacionadas-ao-trabalho/. Acesso em: 22 abr. 2019.

PASSARINHO, Nathalia. Fiscalização de barragens: órgão federal de controle é o $2^{\circ}$. mais exposto a fraudes e corrupção, diz TCU, 13 fev. 2019. Disponível em: https://www. bbc.com/portuguese/brasil-47211131. Acesso em: 22 abr. 2019.

PEREIRA, Caio Mário da Silva. Responsabilidade Civil, 9. ed. Rio de Janeiro: Forense, 2001.

PINASSI, Maria Orlanda. Da miséria ideológica à crise do capital: uma reconciliação histórica. São Paulo: Boitempo, 2009.

PINTO, José Augusto Rodrigues. Breves cogitações sobre a responsabilidade no direito do trabalho. Revista de Direito do Trabalho, São Paulo, v. 31, n. 117, jan./mar. 2005.

RODRIGUES, Silvio. Direito civil: responsabilidade civil, 20. ed. São Paulo: Saraiva, 2003, v. 4.

SENRA, Ricardo. Brumadinho, a história de uma tragédia que poderia ter sido evitada, 28 fev. 2019. Disponível em: https://www.bbc.com/portuguese/brasil-47399659. Acesso em: 22 abr. 2019.

SILVA, Kalina Vanderley; SILVA, Maciel Henrique. Dicionário de Conceitos Históricos, 4. ed. São Paulo: Contexto, 2012.

SILVA, Leda Maria Messias; BEZERRA, Christiane Singh. A responsabilidade pré-contratual e pós-contratual com vistas ao direito da personalidade nas relações de trabalho. In: 
CONGRESSO NACIONAL DO CONPEDI, 17, 2008, Brasília. Anais...Brasília: CONPEDI, 2008.

SOUTO MAIOR, Jorge Luiz. Solidariedade e respeito às vítimas da Vale em Brumadinho, 27 jan. 2019. Disponível em: https:/www.jorgesoutomaior.com/blog/solidariedade-e-respeito-as-vitimas-da-vale-em-brumadinho. Acesso em: 22 abr. 2019.

STOCO, Rui. Tratado de responsabilidade civil: responsabilidade civil e sua interpretação doutrinária e jurisprudencial, 5. ed. São Paulo: Revista dos Tribunais, 2001.

TUPONI JUNIOR, Benedito Aparecido. Responsabilidade civil objetiva e atividades empresariais de risco: fundamentos, abrangência, e critérios de aplicabilidade na infortunística trabalhista, 2008. Dissertação (Mestrado em Direito) - Centro Universitário de Curitiba, Programa de Pós-Graduação em Direito, Curitiba, 2008.

VAZ, Caroline. Funções da responsabilidade civil: da reparação à punição e dissuasão os punitive damages no direito comparado e brasileiro. Porto Alegre: Livraria do Advogado Editora, 2009.

\section{DAdos das AUtoras}

\section{Débora de Jesus Rezende Barcelos}

Mestranda em Direito pela Pontifícia Universidade Católica de Minas Gerais. Especialista em Direito do Trabalho e Previdenciário pela mesma instituição. Bacharel em Direito pela Faculdade Mineira de Direito da Pontifícia Universidade Católica de Minas Gerais (PUC Minas).deboradejesus.barcelos@gmail.com.

\section{Carolina de Souza Novaes Gomes Teixeira}

Doutora e mestre pela Pontifícia Universidade Católica de Minas Gerais. Graduação em Direito pela Universidade Federal de Ouro Preto (2011). Especialista em Direito Privado pela Universidade Cândido Mendes - RJ e em Direito da Propriedade Intelectual pela Justus Liebig Universitat - Giessen, Alemanha. carolinasnovaes@gmail.com.

Submetido em: 27-6-2020

Aceito em: 23-10-2020 